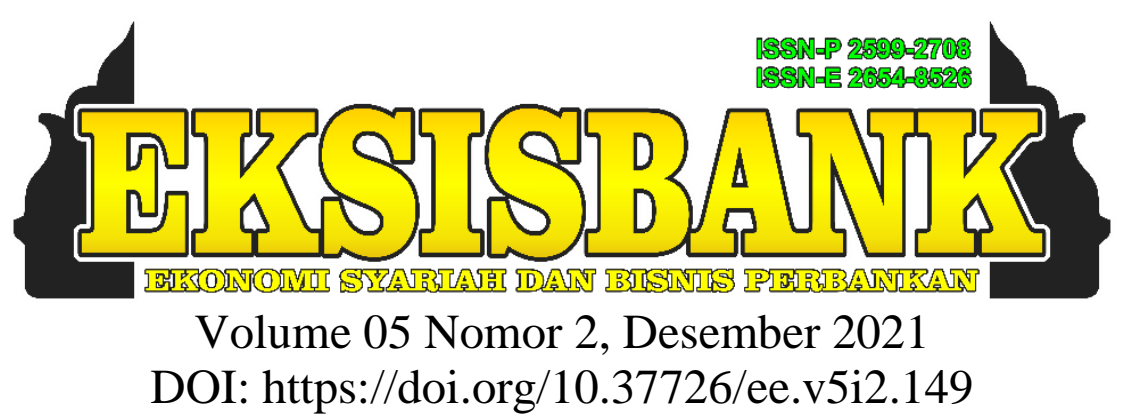

\title{
Pengaruh Faktor Sosial Dan Pribadi Terhadap Minat Beli Produk Peyek Aziz Tanpa Tanggal Kedaluwarsa Dalam Perspektif Ekonomi Syariah
}

\author{
Wiwi Mulyani ${ }^{1}$, Ai Siti Khoeriah ${ }^{2}$, Saepul Bahri ${ }^{3}$ \\ ${ }^{1,3}$ Sekolah Tinggi Ilmu Ekonomi Syariah (STIES) Indonesia Purwakara \\ ${ }^{2}$ PAUD Khoirul Maqam Simpang Purwakarta \\ ${ }^{1}$ wwmulyani@gmail.com \\ 2aisitikhoeriah@gmail.com \\ ${ }^{3}$ saepulbahri@gmail.com
}

\begin{abstract}
ABSTRAK
Melaksanakan kegiatan ekonomi berdasarkan Islam adalah perintah dan bernilai ibadah. Secara kaidah fiqh setiap transaksi muammalah dibolehkan selama tidak bertentangan dengan dasar hukum Islam yakni al-Quran dan hadits termasuk menjalankan kegiatan ekonomi dalam bidang usaha pengolahan makanan peyek. Tujuan penelitian ini untuk mengetahui pengaruh faktor sosial dan pribadi terhadap minat beli produk Peyek Aziz tanpa tanggal kedaluwarsa dalam perspektif ekonomi syariah. Metode yang digunakan adalah deskriptif kuantitatif dengan jumlah sample yang gunakan sebanyak 33 responden yang berada di lingkungan kelurahan Kertamukti kecamatan Campaka yang ditentukan melalui probability sampling dengan teknik random sampling. Hasil dari penelitian ini diketahui faktor pribadi mempengaruhi minat beli konsumen dengan nilai signifikansi $0.000<0.05$. Faktor sosial dinyatakan tidak mempengaruhi karena nilai signifikansi yang diperoleh adalah $0.063>0.05$. Sedangkan faktor sosial dan pribadi secara bersama-sama mempengaruhi minat beli konsumen dengan nilai signifikansinya sebesar $0.000<0.05$. Berdasarkan hasil tersebut diketahui faktor sosial dan pribadi mempengaruhi minat beli konsumen makanan tanpa tanggal kedaluwarsa sebesar 0.515 atau $51 \%$. Sedangkan sisanya $49 \%$ dipengaruhi oleh faktor lain yang tidak diteliti. Tinjauan ekonomi Syariah terkait makanan tanpa label kedaluwarsa tidak ditemukan keterangan yang mengatur secara khusus. Pencantuman label kedaluwarsa merupakan ijtihad dalam memberi informasi batas waktu layak konsumsi pada produk makanan dengan tujuan kemaslahatan dalam memelihara harta dan jiwa.
\end{abstract}

Kata kunci : Faktor Sosial \& Pribadi, Minat Beli, Peyek, Tanggal Kedaluarsa 


\section{ABSTRACT}

Carrying out economic activities based on Islam is an order and has the value of worship. According to figh rules, every muammalah transaction is allowed as long as it does not conflict with the basic Islamic law, namely the Qur'an and hadith, including carrying out economic activities in the field of food processing business. The purpose of this study was to determine the influence of social factors and personal factors on consumer buying interest in Peyek Aziz. products. The method used is descriptive quantitative with the number of samples used as many as 33 respondents in the Kertamukti sub-district, Campaka sub-district which was determined through probability sampling with random sampling technique. The results of this study indicate that personal factors affect consumer buying interest with a significance value of $0.000<$ 0.05. Social factors are declared not to affect because the significance value obtained is $0.063>0.05$. While social and personal factors jointly affect consumer buying interest with a significance value of $0.000<0.05$. Based on these results, it is known that social and personal factors affect consumer buying interest in food without an expiration date of 0.515 or $51 \%$. While the remaining $49 \%$ is influenced by other factors not examined. The sharia economic review regarding food without expired labels did not find any specific regulatory information. The inclusion of an expired label is an ijtihad in providing information on the appropriate time limit for consumption on food products with the aim of benefiting in maintaining property and life.

Keywords: Social \& Personal Factors, Buying Interest, Teek, Expiration Date

\section{PENDAHULUAN}

Sistem ekonomi Islam memiliki tujuan untuk menciptakan keadaan yang lebih baik bagi umat manusia dalam berkehidupan, dengan dasar hukum yang bersumber dari al-Qur'an dan Hadits untuk terapkan implementasinya pada kehidupan sehari-hari (Fahmi 2016). Dalam ajaran Islam, aktivitas ekonomi tidak dapat dilepaskan dari nilai-nilai dasar yang telah ditetapkan dalam Al-Qur'an, Hadits Nabi, dan sumber-sumber ajaran Islam lainnya. Ekonomi Islam, sebagaimana dinyatakan oleh Muhammad Nejatullah Siddiqi, merupakan jawaban dari pemikir Muslim terhadap tantangan ekonomi pada zamannya yang didasarkan pada Al-Qur'an dan Sunnah Nabi, akal fikiran, serta pengalaman. Islam sarat dengan nilai-nilai yang mendorong manusia untuk membangun ekonomi mereka yang tercermin dalam anjuran disiplin waktu, memelihara harta, nilai kerja, meningkatkan produksi, menetapkan konsumsi, dan juga perhatian Islam terhadap ilmu pengetahuan (Idri 2017).
Berdasarkan pada definisi di atas dapat ditarik pemahaman bahwa prinsip ekonomi Islam merupakan penerapan asas efisiensi dan manfaat dengan tetap menjaga kelestarian lingkungan alam. Asas ekonomi Islam adalah mencapai keberuntungan di dunia dan di akhirat oleh manusia selaku khalifah Allah dengan jalan beribadah dalam arti yang lebih luas. Upaya pemerintah dalam untuk menurunkan tingkat kesenjangan sosial salah satunya adalah melalui pertumbuhan home industry. Home industry adalah industri kecil yang berproduksi di rumah atau perumahan, perkampungan.

Makanan yang halal dan baik yaitu adalah makanan yang dibolehkan oleh agama dari segi hukumnya, baik halal dzatnya, dibolehkan oleh agama. firman Allah SWt dalam surat al-Maidah ayat 88 berikut:

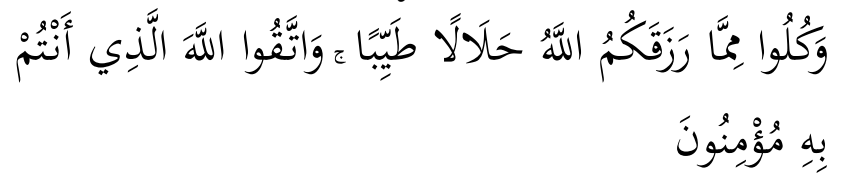


Dan makanlah makanan yang halal lagi baik dari apa yang Allah Telah rezekikan kepadamu, dan bertakwalah kepada Allah yang kamu beriman kepada-Nya (Enang 2010).

Berdasarkan surat al-Maidah ayat 88 diatas, Allah memerintahkan kepada hambanya agar mereka makan rezeki yang halal dan baik, yang telah dikaruniakannya kepada mereka "halal" disini mengandung pengertian halal bendanya dan halal cara memperolehnya. Sedangkan "baik" adalah dari segi kemanfaatannya, yaitu yang mengandung manfaat dan maslahat bagi tubuh, mengandung gizi, vitamin, protein dan sebagainya. Makan tidak baik, selain tidak mengandung gizi, juga jika dikonsumsi akan merusak kesehatan. Maka Allah memerintahkan kita untuk memakan makanan yang bukan cuma halal, tapi juga baik (Halalan Thayyiban) agar tidak membahayakan tubuh kita. Bahkan perintah ini disejajarkan dengan bertakwa kepada Allah, sebagai sebuah perintah yang sangat tegas dan jelas.

Berdasarkan ayat al-Quran diatas Allah menyeru kepada rasul-Nya agar selalu bersyukur terhadap nikmatnya melalui hadits berikut:

عَنْ اََبْ هُرَيْرَةَ رَضِيَ اللهُ عَنْهُ قَا لَ: قَا لَ رَسُوْلُ الله

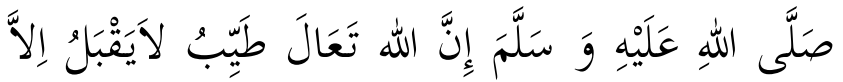

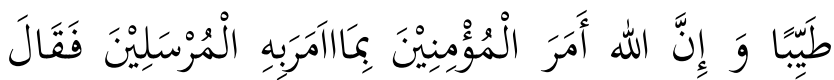

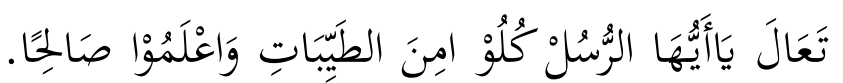

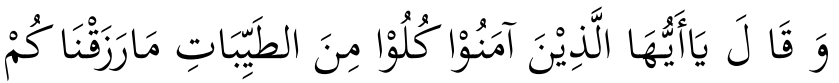

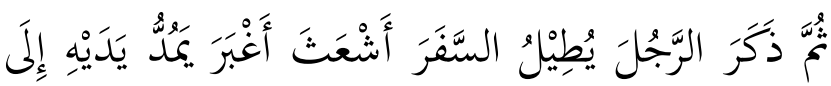

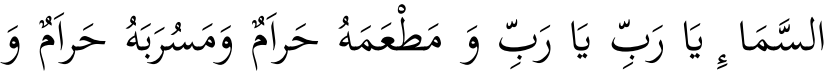

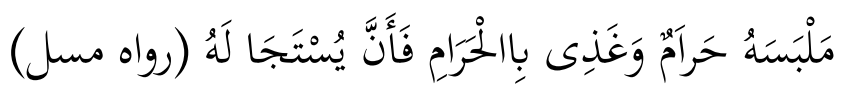

Dari Abu Hurairah r.a. ia berkata, "Rasullulah SAW bersabda, sesungguhnya Allah itu baik, tidak menerima kecuali yang baik. Dan sesungguhnya Allah telah memerintahkan pada orang-orang mukmin seperti apa yang telah diperintahkan-Nya kepada Rasul, maka Allah berfirman: Hai para Rasul, makanlah kamu semua dari sesuatu yang baik dan berbuatlah kamu yang baik. Dan firman Allah yang lain: Hai orang-orang yang beriman, makanlah kamu semua dari sebaik-baik apa yang telah Ku-rezekikan kepadamu. Kemudian Nabi SAW menceritakan seseorang lelaki yang telah jauh perjalanannya dengan rambutnya yang kusut, kotor, penuh debu, yang menadahkan kedua tangannya seraya berkata (berdo'a): Wahai tuhanku, sedangkan makanannya haram minumannya haram, pakaiannya haram dan dikenyangkan barang yang haram, mana mungkin ia akan dikabulkan do'anya? " (HR. Muslim) (Muslim 1998).

Berdasarkan hadits diatas, Allah memerintahkan kepada orang-orang yang beriman agar memakan semua makanan dari sesuatu yang baik dan berbuatlah yang baik. berlandaskan pada ayat-ayat al-Quran dan Hadist diatas Peyek produksi ibu Warsiyati secara bahan baku dan pengolahannya merupakan makan yang baik dan halal untuk di konsumsi baik untuk sendiri maupun oleh masyarakat umum dengan transaksi jual beli dalam proses perpindahan hak kepemilikannya.

Makanan peyek ibu Warsiyati diproduksi secara mandiri dan dipasarkan secara tradisional dari warung ke warung. Peyek yang dipasarkan ibu Warsiyati belum memiliki tanggal kedaluwarsa yang di cantumkan. Dengan demikian peyek yang dipasarkan belum memberikan informasi yang mudah kepada konsumen terkait masa layak untuk 
konsumsi dan masa sudah tidak layak konsumsi.

Berdasarkan dasar hukum Islam sendiri, penulis belum menemukan adanya hukum khusus yang mengatur kewajiban pelaku usaha untuk mencantumkan tanggal kedaluwarsa dan hukum melarang atau membolehkan menjual makanan kemasan yang tidak mencantumkan tanggal kedaluwarsa .

Berdasarkan pada latar belakang di atas, maka peneliti ini penting untuk dilakukan sebagai sarana informasi masyarakat terkait makanan tanpa masa kedaluwarsa, dan faktor yang mempengaruhi konsumen dalam membeli produk makanan tanpa informasi tanggal kedaluwarsa.

Tujuan penelitian ini adalah untuk mengetahui pengaruh faktor sosial terhadap minat beli produk Peyek Aziz tanpa tanggal kedaluwarsa dalam perspektif ekonomi syariah; Untuk mengetahui pengaruh faktor pribadi terhadap minat beli produk Peyek Aziz tanpa tanggal kedaluwarsa dalam perspektif ekonomi syariah; Untuk mengetahui pengaruh faktor sosial dan pribadi terhadap minat beli produk Peyek Aziz tanpa tanggal kedaluwarsa dalam perspektif ekonomi syariah; dan untuk mengetahui pandangan ekonomi syariah terhadap produk makanan tanpa tanggal kedaluwarsa.

\section{TINJAUAN PUSTAKA \\ A. Pengertian Perilaku Konsumen}

Menurut Peter Olson perilaku konsumen (consumer behavior) didefinisikan sebagai studi tentang unit pembelian (buying units) dan proses pertukaran yang melibatkan perolehan, konsumsi, dan pembuangan barang, jasa, pengalaman, serta ide-ide. Asosiasi pemasaran Amerika mendefinisikan perilaku konsumen sebagai interaksi yang dinamis mengenai perasaan, kognisi, perilaku, dan lingkungan dimana individu melakukan pertukaran dalam berbagai aspek didalam kehidupannya (Peter, J Paul dan Olson 2010).

Minat seseorang selaku konsumen tidak timbul dengan sendirinya, hal ini dipengaruhi oleh unsur-unsur kebutuhannya. Minat menjadi ada karena pengaruh dari beberapa faktor. Menurut Crow and Crow, ada tiga faktor yang menimbulkan minat yaitu, faktor yang timbul dari dalam diri individu, faktor motif sosial dan faktor emosional yang ketiganya mendorong timbulnya minat. Pendapat tersebut sejalan dengan yang dikemukakan Sudarsono, faktor-faktor yang menimbulkan minat dapat digolongkan sebagai berikut (Payne Andrian 2009):

1. Faktor kebutuhan dari dalam. Kebutuhan ini dapat berupa kebutuhan yang berhubungan dengan jasmani dan kejiwaan.

2. Faktor motif sosial, Timbulnya minat dalam diri seseorang dapat didorong oleh motif sosial yaitu kebutuhan untuk mendapatkan pengakuan, perhargaan dari lingkungan dimana ia berada.

3. Faktor emosional. Faktor ini merupakan ukuran intensitas seseorang dalam menaruh perhatian terhadap sesuat kegiatan atau objek tertentu.

\section{B. Faktor-faktor yang mempengaruhi Per- ilaku Konsumen}

Faktor-faktor yang mempengaruhi perilaku konsumen menurut Agustina Shinta merupakan perilaku yang ditujukan oleh konsumen melalui pencarian, pembelian, penggunaan, pengevaluasian dan penentuan produk atau jasa dalam memenuhi harapan dan kepuasan (kebutuhan) pribadi konsumen (Shinta Agustina 2011).

Berikut ini merupakan faktor-faktor yang mempengaruhi perilaku konsumen, yaitu:

1. Faktor-faktor Kebudayaan

a. Kebudayaan. Kebudayaan merupakan faktor penentu yang paling dasar 
dari keinginan dan perilaku seseorang. Bila makhluk-makhluk lainnya bertindak berdasarkan naluri, maka perilaku manusia umumnya dipelajari.

b. Subbudaya. Subbudaya dapat dibedakan menjadi empat jenis: kelompok nasionalisme, kelompok keagamaan, kelompok ras, dan area geografis.

c. Kelas sosial. Kelas-kelas sosial adalah kelompok yang relative homogen dan bertahan lama dalam suatu masyarakat, yang tersusun secara hierarki dan yang keanggotaannya mempunyai nilai, minat, dan perilaku yang serupa (Simamora Bilson 2003).

2. Faktor-faktor Sosial

a. Kelompok referensi. Kelompok referensi seseorang terdiri dari seluruh kelompok yang mempunyai pengaruh langsung maupun tidak langsung terhadap sikap atau perilaku seseorang.

b. Keluarga. Kelompok keluarga yang pertama ialah: keluarga orientasi, yang merupakan orang tua seseorang. Dari orang tualah seseorang mendapatkan pandangan tentang agama, politik, ekonomi, dan merasakan ambisi pribadi nilai atau harga diri dan cinta.

c. Peran dan status. Seseorang umumnya berpartisipasi dalam kelompok selama hidupnya keluarga, klub, organisasi. Posisi seseorang dalam setiap kelompok dapat diidentifikasikan dalam peran dan status (Simamora Bilson 2003).

3. Faktor-faktor Pribadi

a. Umur dan tahapan dalam siklus hidup. Konsumsi seseorang juga dibentuk oleh tahapan siklus hidup keluarga.

b. Pekerjaan atau kelompok-kelompok pekerja yang memiliki minat diatas rata-rata terhadap produk dan jasa tertentu.

c. Keadaan ekonomi. Yang dimaksud dengan kedaan ekonomi seseorang adalah terdiri dari pendapatan yang dapat dibelanjakan (tingkatnya, stabilitasnya, dan polanya), tabungan dan hartanya (termasuk persentase yang mudah dijadikan uang), kemampuan untuk meminjam dan sikap terhadap mengeluarkan lawan menabung.

d. Gaya hidup. Gaya hidup seseorang adalah pola hidup di dunia yang diekspresikan oleh kegiatan, minat, dan pendapat seseorang. Gaya hidup menggambarkan :seseorang secara keseluruhan yang berinteraksi dengan lingkungan.

e. Kepribadian dan konsep diri merupakan karakteristik psikologis yang berbeda dan setiap orang yang memandang responsnya terhadap lingkungan yang relative konsisten.

\section{Faktor-faktor Psikologis}

a. Motivasi. Beberapa kebutuhan bersifat biogenic, kebutuhan ini timbul dari suatu fisiologis tertentu, seperti rasa lapar, haus, resah tidak nyaman. Adapun kebutuhan lain bersifat psikogenik, yaitu kebutuhan yang timbul dari keadaan fisiologis tertentu,seperti kebutuhan untuk diakui, kebutuhan harga diri atau kebutuhan diterima (Simamora Bilson 2003).

\section{C.Faktor-faktor yang Mempengaruhi Minat Beli Konsumen}


Menurut Lidyawatie menjelaskan bahwa ada beberapa faktor yang mempengaruhi minat beli konsumen, yaitu:

1. Perbedaan pekerjaan, artinya dengan perbedaan pekerjaan seseorang dapat diperkirakan minat terhadap tingkat pekerjaan yang ingin dicapainya, aktivitas yang dilakukan, penggunaan waktu luang, dan lainnya

2. Perbedaan sosial ekonomi, artinya seseorang yang mempunyai sosial ekonomi tinggi akan lebih mudah mencapai apa yang diinginkannya daripada yang mempunyai sosial ekonomi rendah.

3. Perbedaan hobi atau kegemaran, artinya bagaimana seseorang menggunakan waktu senggangnya.

4. Perbedaan jenis kelamin, artinya minat wanita akan berbeda dengan minat pria, misalnya dalam pola belanja.

5. Perbedaan usia, artinya usia anak-anak, remaja, dewasa dan orang tua akan berbeda minatnya terhadap suatu barang, aktivitas benda dan seseorang (Lidyawatie 2008).

\section{Rempeyek Atau Peyek}

Rempeyek atau peyek merupakan jenis makanan atau kue gorengan yang bisa disajikan dan dinikmati dengan beraneka hidangan. Peyek bisa dinikmati langsung sebagai camilan atau makanan ringan, sebagai kerupuk teman makan nasi, atau disajikan sebagai bahan variasi pelengkap pecal, gadogado dan rujak. Rempeyek yang disukai oleh berbagai kalangan ini bisa dengan mudah ditemukan dijual di warung makan, pasar, ataupun di pasar swalayan. Di daerah pedesaan, peyek biasanya disajikan dalam acara pernikahan, kenduri, dan beragam acara kekeluargaan lainnya (Bourdieu Piere 2015).

Menurut Dee Graaf dalam tulisannya "Mataram Islam" nama rempeyek telah ada sejak abad ke 16 di Yogyakarta. Istilah Rempeyek atau Peyek kata tersebut berasal dari pengucapan masyarakat pada yang berdasar pada kata rempah - rempah dan jiyek yang berarti gepeng, maka di kenal peyek atau rempeyek. Hal ini mengacu pada bahan dasar yakni rempah-rempah yang digunakan sebagai bahan masakan serta jiyek yang memiliki arti gepeng dan lebar. Komposisi atau isian dari Peyek secara umum merupakan adalah biji kacang tanah atau kedelai. Disamping dari kacang tanah atau kacang kdelai peyek juga di isi dengan varian yang berbeda. Di beberapa tempat peyek di isi oleh ikan teri kecil, rebon serta kacang-kacang jenis lain selain kacang tanah dan kacang kedelai. selain jenis kacang-kacangan, peyek juga bisa diisi dengan bahan pangan hewani berukuran kecil, seperti ikan teri, ebi, udang kecil, potongan ikan asin atau potongan belut. Bahkan, saat ini orang juga membuat peyek dari daun bayam (Sarastri Mumpuni dan Idea Prajna Paramitha 2013).

\section{E. Makanan Tanpa Tanggal Kedaluarsa}

Menurut BPOM, makanan dinyatakan mengalami kerusakan (telah kedaluwarsa) jika telah terjadi perubahan-perubahan yang tidak dikehendaki dari sifat asalnya. Kerusakan pada makanan dapat terjadi karena kerusakan fisik, kimia atau enzimatis (Haris Hamid 2017). Perilaku Konsumen Islami Syariah Islam menginginkan manusia mencapai dan memelihara kesejahteraannya. Pola konsumsi pada masa kini lebih menekankan aspek pemenuhan keinginan material daripada aspek kebutuhan yang lain.

Pada produk makanan, minuman, obatobatan atau apa saja informasi tentang tanggal kedaluwarsa sangatlah penting untuk dicantumkan guna melindungi konsumen dari bahaya keracunan produk kedaluwarsa. Pencantuman tanggal kedaluwarsa ditulis pada kemasan produk dan informasi tentang 
tanggal kedaluwarsa merupakan produk yang diproduksi dalam jumlah yang banyak oleh pabrik atau industri.

Bahaya makanan kedaluwarsa bisa mengakibatkan gangguan pencernaa, gangguan kesehatan dan bias mengakibatkan kematian untuk kasus yang serius jika tidak segera tertangani. Efek dari keracunan oleh makanan kedaluwarsa pada gejala yang muncul atau dirasakan oleh konsumen tidak berbeda dengan keracunan pada makanan. Gejala yang timbul seperti mual-mual, pusing, muntah-muntah, diare dan gejala keracunan lainya.

\section{F. Pandangan Ekonomi Syariah Terhadap Makan Tanpa Label Kedaluarsa}

Pandangan Ekonomi Syariah terhadap makan tanpa label kedaluarsa secara umum tidak ditemui dasar hukumnya pada al-Quran dan Hadits. Dalam ajaran fiqh, islam mengajarkan umatnya untuk mengkonsumsi sesuatu yang halal dan baik. Baik itu dari segi manfaat makanannya maupun dari cara memperolehnya.

Allah telah membuat kriteria makanan yang boleh dikonsumsi dengan standar halalan tayyiban. Pengertian halalan disini berarti jenis makanan yang diperbolehkan dikonsumsi dan tidak diharamkan. Sedangkan pengertian tayyiban berarti semua jenis makanan yang member manfaat manusia karena telah memenuhi syarat kesehatan (misalnya: gizi, protein,higienis, dan lainlain) tidak najis, tidak memabukkan, tidak membawa pengaruh negative bagi kesehatan fisik dan psikis, serta diperoleh dengan cara halal.

Perintah Allah SWT kepada umat manusia untuk mengkonsumsi makanan yang baik teleh jelas tertulis dalam al-Quran, salah satunya firman Allah dalam surat Al-Baqarah ayat 168 disebutkan bahwa Allah memberikan perintah yang tegas untuk memakan makanan yang halal dan baik, firman Allah dala surat al-Baqarah ayat 168 tersebut berbunyi sebagai berikut:

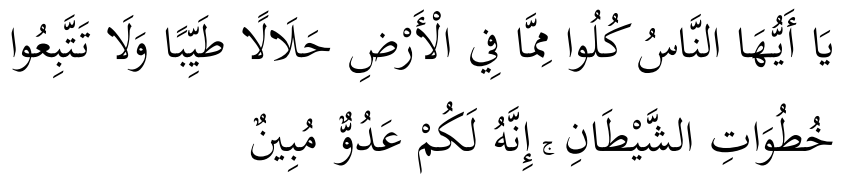

"Hai sekalian manusia, makanlah yang halal lagi baik dari apa yang terdapat di bumi, dan janganlah kamu mengikuti langkah-langkah syaitan; Karena Sesungguhnya syaitan itu adalah musuh yang nyata bagimu”

Berdasarkan ayat al-Quran diatas makanan-makanan halal dapat dikategorikan sebagai berikut:

1. Semua makanan yang baik.

2. Semua makanan yang tidak diharamkan oleh Allah dan Rasulnya.

3. Semua makanan yang tidak member mudharat.

4. Semua binatang yang dihalalkan Allah dan Rasulnya (Shihab 2002).

Berdasarkan pembahasan diatas, maka dapat ditarik pemahaman yakni kaitannya dengan tinjauan ekonomi syariah terhadap makanan tanpa label kedaluarsa adalah bahwa penerapan label kedaluarsa pada makanan merupakan upaya dalam memberi kejelasan batas waktu baik untuk mengkonsumsi produk makanan tersebut. Al-Qur'an dan Hadis perlu didasarkan pada rasionalitas yang disempurnakan dengan mengintegrasikan keyakinan kepada kebenaran yang melampaui rasionalitas manusia (Isnaini Harahap Dkk 2015).

\section{METODOLOGI PENELITIAN}

Peneletian ini menggunakan metode Deskriptif Kuantatif. Menurut Syamsudin \& Damiyanti metode penelitian Deskriptif kuantitatif merupakan metode penelitian yang bertujuan menjelaskan fenomena yang ada dengan menggunakan angka-angka untuk 
menstandarkan karakteristik individu atau kelompok (Syamsuddin and Damaianti 2011).

Variabel bebas ialah antecedent dan variabel Dependen ialah Konsekuensi. Variabel penelitian umumnya dibagi atas 2 jenis, yaitu variabel Kontinu dan varaiabel Deskrit. Variabel juga dapat dilihat sebagai variabel Independen dan Dependen. Serta variabel dapat dilihat sebagai variabel aktif dan atribut. Secara garis besar variabel yang digunakan dalam penelitian ini dibagi menjadi dua yaitu variabel Independent atau bebas $(\mathrm{X})$ dan variabel Dependent atau terikat (Y) (Moh. Nazir 2014).

Variabel Independen dalam penelitian ini ialah Faktor sosial $\left(\mathrm{X}_{1}\right)$ dan faktor pribadi $\left(\mathrm{X}_{2}\right) . \mathrm{X}_{1}$ dan $\mathrm{X}_{2}$ dinyatakan dapat memberikan pengaruh terhadap variabel Dependen (Y) pada penelitian ini yaitu minat beli. Faktor sosial $\left(\mathrm{X}_{1}\right)$ dan Faktor pribadi $\left(\mathrm{X}_{2}\right)$ diukur berdasarkan ratio faktor sosial dan pribadi yang mendorong masyarakat untuk berbelanja produk. Variabel Y (minat beli) terpengaruh oleh variabel $\mathrm{X}$ pada penelitian ini dapat diukur berdasarkan ratio tingkat kesenangan masyarakat dalam melakukan pembelian produk (Arikunto 2016).

Menurut Suharsimi Arikunto Populasi merupakan seperangkat unit analisis yang lengkap yang dapat diteliti, merupakan keseluruhan dari objek atau individu yang memiliki karakteristik atau sifat-sifat tertentu yang akan diteliti (Arikunto 2016). Populasi yang akan di teliti dalam dalam penelitian ini merupakan konsumen yang melakukan pembelian produk makanan ringan Peyek produksi Home Industry ibu Warsiyati. Frekuensi pembelian konsumen atau masyarakat terhadap peyek produksi dari Home industry ibu Warsiyati diukur berdasarkan waktu penelitian.

Menurut Suharsimi Arikunto Sampel merupakan penelitian yang dilakukan terhadap sebagian saja atau wakil dari populasi, akan tetapi hasil penelitiannya berlaku bagi semua subjek yang tergabung sebagai populasi. Penentuan jumlah anggota sampel dari populasi dalam penelitian ini adalah dengan menggunakan terapan Rumus Slovin yang di hitung berdasarkan populasi yang di tentukan jumlahnya dilapangan. Adapaun perhitungan menggunakan rumus slovin tersebut sebagai berikut :(Juliansyah Noor 2011)

$$
\mathrm{n}=\frac{50}{1+\left(50 \times 0,1^{2}\right)}=33
$$

Dengan demikian sample yang digunakan pada penelitian ini dengan tingkat error $10 \%$ atau 0,1 dari populasi sebanyak 50 responden yang digunkan pada kurun waktu penelitian adalah sebanyak 33 responden. Sampel yang diamati dalam penelitian ini merupakan setiap masyarakat yang melakukan perbelanjaan produk makan Peyek dari Home Industry ibu Warsiyati berhasil ditemui selama penelitian ini berlangsung. Karakteristik responden diukur meliputi :

a. Konsumen laki laki yang melakukan pembelian Produk Makanan Peyek dari Home Industry ibu Warsiyati.

b. Konsumen perempuan yang melakukan pembelian Produk Makanan Peyek dari Home Industry ibu Warsiyati.

c. Pemuda/i Pelajar SMA, SMP dan mahasiswa yang melakukan melakukan pembelian Produk Makanan Peyek dari Home Industriy Ibu Warsiyati.

d. Masyarakat di Kecamatan Campaka memiliki pengetahuan tentang Peyek.

Data primer dalam penelitian ini ialah data yang diperoleh dari kuesioner yang diberikan peneliti kepada responden. Data sekunder menurut Mudrajat Kuncoro (Mudrajad Kuncoro 2014), merupakan data yang diperoleh dari buku-buku atau literatur yang berhubungan dengan masalah yang teliti meliputi data yang diperoleh dari buku, artikel, 
jurnal, data dari internet, dan skripsi penelitian sebelumnya.

Dalam mengetahui pendapat responden dalam menjawab pertanyaan-pertanyaan yang sudah diajukan, maka digunakan pendekatan Skala Likert dengan menggunakan 5 kategori, hal ini dapat dilihat pada gambar berikut:

Tabel 3.5.2

Model Skala Likert

\begin{tabular}{|c|c|c|c|c|}
\hline $\begin{array}{c}\text { Sangat } \\
\text { Setuju }\end{array}$ & $\begin{array}{c}\text { Set- } \\
\text { uju }\end{array}$ & $\begin{array}{c}\text { Ragu- } \\
\text { ragu }\end{array}$ & $\begin{array}{c}\text { Tidak } \\
\text { Setuju }\end{array}$ & $\begin{array}{c}\text { Sangat } \\
\text { Tidak Set- } \\
\text { uju }\end{array}$ \\
\hline$($ SS $)$ & $($ S) & (RG) & $($ TS $)$ & (STS) \\
\hline 5 & 4 & 3 & 2 & 1 \\
\hline
\end{tabular}

Sumber: Dokumen Penulis

Berdasarkan table diatas, pengujian data pada penelitian ini adalah dengan menggunakan uji validitas, uji realibilitas, uji normalitas, uji multikolinieritas, uji heteroskedastis, uji parsial, uji simultan (uji f), dan uji r-square (uji r2) (Sugiyono 2006). Adapun hipotesis yang digunakan pada penelitian ini adalah sebagai berikut:

1. Faktor Sosial

Ho : Tidak ada pengaruh faktor sosial terhadap minat beli konsumen.

$\mathrm{Ha}$ : Ada pengaruh faktor sosial terhadap minat beli konsumen.

2. Faktor Pribadi

Ho : Tidak ada pengaruh faktor pribadi terhadap minat beli konsumen

Ha : Ada pengaruh faktor pribadi terhadap minat beli konsumen

3. Faktor Sosial dan Faktor Pribadi

Ho : Tidak ada pengaruh faktor sosial dan faktor pribadi terhadap minat beli konsumen

Ha : Ada pengaruh faktor sosial dan faktor pribadi terhadap minat beli konsumen

\section{HASIL DAN PEMBAHASAN A. Deskripsi Objek Penelitian}

Home Industry Peyek berada di Desa Kertamukti Kecamatan Campaka dan merupakan usaha yang rintis dan di bangun oleh Ibu Warsiyati. Awal usahanya dijalankan oleh orang tuanya di Yogyakarta. Peyek Aziz merupakan olahan sejenis makanan ringan dari kota Yogyakarta. Bentuk dan karekteristik peyek serupa dengan makanan "Gorengan" di Purwakarta perbedaaanya terdapat pada cita rasa. Berikut ini sejarah singkat terkait awal mula Home Industry Peyek ini berdiri,

1. Pada awal tahun 2004 pindah ke kota Tangerang Karena ikut suami dan mulai berjualan peyek pada tahun 2011

2. Pada tahun 2013 suami dipindah tugaskan pekerjannya dari Tangerang Ke Purwakarta. Kami turut pindah ke Purwakarta.

3. Awal tahun tahun 2017 mulai terbesit untuk kembali membangun usaha Peyek seperti saat di Tangerang. Dan sebagai upaya mempertahankan usaha warisan keluarga.

4. Pada 1 Juli 2017 secara resmi kami membuka usaha Peyek Aziz sampai dengan sekarang.

5. Peyek Aziz dipilih sebagai brand produk untuk menjadi ciri khas pada produk. nama Peyek diambil dari nama makanan itu sendiri sedangkang nama aziz merupakan nama anak dari kami.

Besar harapan kami, semoga di kemudian hari usaha sudah di bangun sampai dengan seperti ini bisa berkembang lagi dan dapat memberi manfaat kepada lingkungan sekitar .

Proses pembuatan peyek Aziz melalui beberapa tahapan, di mulai dari tahap mencampurkan bahan dan proses pembuatan adonan peyek, proses penggorengan dan proses penirisan produk, hingga pada proses pengemasan produk dan proses pemasaran produk peyek.

\section{B. Hasil Uji Statistik}




\section{Uji Validitas}

Uji validitas digunakan untuk mengukur ketetapan suatu item dari kuesioner atau skala yang ingin diukur. Dalam menentukan valid atau tidaknya item digunakan kegiatan yang harus dilakukan adalah dengan membandingkan rhitung dengan rtabel dimana tarif signifikansi yang digunakan adalah 0.05. Untuk mengetahui tingkat validitas tersebut, maka akan dilakukan terlebih dahulu uji statistik dengan menggunakan SPSS 22, adapun hasil outputnya dapat dilihat dari tabel dibawah ini.

Tabel 4.1

Hasil Uji Validitas Faktor Sosial $\left(\mathrm{X}_{1}\right)$

\begin{tabular}{|c|c|c|c|}
\hline No & R Hitung & R Tabel (0.05) & Keterangan \\
\hline 1 & 0.684 & 0.3440 & Valid \\
\hline 2 & 0.837 & 0.3440 & Valid \\
\hline 3 & 0.846 & 0.3440 & Valid \\
\hline
\end{tabular}

Sumber : Data Primer 2018 (Diolah)

Dapat dilihat bahwa berdasarkan tabel diatas, secara keseluruhan item pertanyaan pada variabel $\mathrm{X}_{1}$ dapat dinyatakan valid karena seluruh item pertanyaan memiliki nilai $r_{\text {hitung }}$ yang lebih besar dari $\mathrm{r}_{\text {tabel }}$ yaitu item 1 dengan nilai sebesar $0.684>0.3440$, item 2 sebesar $0.837>0.3440$, item 3 sebesar $0.846>$ 0.3440 .

Tabel 4.2

Hasil Uji Validitas Faktor Pribadi

\begin{tabular}{|c|c|c|c|}
\hline No & R Hitung & R Tabel (0.05) & Keterangan \\
\hline 1 & 0.405 & 0.3440 & Valid \\
\hline 2 & 0.568 & 0.3440 & Valid \\
\hline 3 & 0.595 & 0.3440 & Valid \\
\hline 4 & 0.829 & 0.3440 & Valid \\
\hline 5 & 0.743 & 0.3440 & Valid \\
\hline
\end{tabular}

Sumber : Data Primer 2018 (Diolah)

Dapat dilihat bahwa berdasarkan tabel diatas, secara keseluruhan item pertanyaan pada variabel X2 dapat dinyatakan valid karena seluruh item pertanyaan memiliki nilai $\mathrm{r}_{\text {hitung }}$ yang lebih besar dari $r_{\text {tabel }}$ yaitu item 1 dengan nilai sebesar $0.405>0.3440$, item 2 sebesar $0.568>0.3440$, item 3 sebesar $0.595>$ 0.3440 , item 4 sebesar $0.829>0.3440$, item 5 sebesar $0.743>0.3440$.

Table 4.3

Hasil Uji Validitas Minat Beli (Y)

\begin{tabular}{|c|c|c|c|}
\hline No & R Hitung & R Tabel (0.05) & $\begin{array}{c}\text { Ket- } \\
\text { erangan }\end{array}$ \\
\hline 1 & 0.445 & 0.3440 & Valid \\
\hline 2 & 0.419 & 0.3440 & Valid \\
\hline 3 & 0.642 & 0.3440 & Valid \\
\hline 4 & 0.701 & 0.3440 & Valid \\
\hline 5 & 0.678 & 0.3440 & Valid \\
\hline 6 & 0.670 & 0.3440 & Valid \\
\hline
\end{tabular}

Sumber : Data Primer 2018 (Diolah)

Dapat dilihat bahwa berdasarkan tabel diatas, secara keseluruhan item pertanyaan pada variabel Y dapat dinyatakan valid karena seluruh item pertanyaan memiliki nilai $\mathrm{r}_{\text {hitung }}$ yang lebih besar dari $r_{\text {tabel }}$ yaitu item 1 dengan nilai sebesar $0.445>0.3440$, item 2 sebesar $0.419>0.3440$, item 3 sebesar $0.642>$ 0.3440 , item 4 sebesar $0.701>0.3440$, item 5 sebesar $0.678>0.3440$, item 6 sebesar $0.670>$ 0.3440 .

\section{Uji Reliabilitas}

Uji reliabilitas digunakan untuk mengetahui konsistensi alat ukur. Dalam hal ini uji reliabilitas dilakukan dengan menggunakan metode Cronbach Alpha dengan kriteria bahwa tingkat alpha dihitung lebih besar dari koefisien Cronbach Alpha sebesar 0.6 maka data yang diajukan memiliki tingkat reliabilitas yang baik.

Tabel 4.4

Uji Reliabilitas

\begin{tabular}{|c|c|c|c|c|}
\hline $\begin{array}{c}\mathrm{N} \\
\mathrm{o}\end{array}$ & Variabel & $\begin{array}{c}\text { Cronbach } \\
\text { Alpha }\end{array}$ & $\begin{array}{c}\text { Cronbach } \\
\text { Alpha Yang } \\
\text { Disyaratkan }\end{array}$ & Ket: \\
\hline 1 & $\begin{array}{c}\text { Faktor } \\
\text { Sosial }\end{array}$ & 0.695 & $>60 \%$ & Reliabel \\
\hline
\end{tabular}

EKSISBANK (Ekonomi Syariah dan Bisnis Perbankan), Volume 5, Nomor 2, Desember 2021 http://journal.sties-purwakarta.ac.id/index.php/EKSISBANK/ 


\begin{tabular}{|c|c|c|c|l|}
\hline $\begin{array}{c}\mathrm{N} \\
\mathrm{o}\end{array}$ & Variabel & $\begin{array}{c}\text { Cronbach } \\
\text { Alpha }\end{array}$ & $\begin{array}{c}\text { Cronbach } \\
\text { Alpha Yang } \\
\text { Disyaratkan }\end{array}$ & Ket: \\
\hline 2 & $\begin{array}{c}\text { Faktor } \\
\text { Pribadi }\end{array}$ & 0.622 & $>60 \%$ & Reliabel \\
\hline 3 & $\begin{array}{c}\text { Minat } \\
\text { Beli }\end{array}$ & 0.613 & $>60 \%$ & Reliabel \\
\hline
\end{tabular}

Sumber : Data Primer 2018 (Diolah)

Berdasarkan tabel diatas dapat dilihat bahwa nilai Cronbach Alpha variabel X1 sebesar 0.695, artinya lebih besar dari 0.6. Kemudian X2 sebesar $0.622>0.6$, dan variabel Y sebesar $0.613>0.6$. Artinya semua variabel dalam penelitian ini dinyatakan reliable.

\section{Uji Normalitas}

Tabel 4.5

Hasil Uji Normalitas

\begin{tabular}{|l|l|r|}
\hline \multicolumn{2}{|c|}{ One-Sample Kolmogorov-Smirnov Test } \\
\hline \multicolumn{2}{|l|}{} & $\begin{array}{c}\text { Unstandardized } \\
\text { Residual }\end{array}$ \\
\hline $\mathrm{N}$ & Mean & 33 \\
\cline { 2 - 3 } $\begin{array}{l}\text { Normal Parame- } \\
\text { ters }{ }^{\mathrm{a}, \mathrm{b}}\end{array}$ & Std. Deviation & .0000000 \\
\hline $\begin{array}{l}\text { Most Extrme Dif- } \\
\text { ferences }\end{array}$ & Absolute & .55682678 \\
\cline { 2 - 3 } & Positive & .086 \\
\cline { 2 - 3 } & Negative &. .086 \\
\hline \multicolumn{2}{|l|}{ Test Statistic } & .086 \\
\hline Asymp. Sig. (2-tailed) & $.200^{\mathrm{c}, \mathrm{d}}$ \\
\hline
\end{tabular}

Uji normalitas digunakan untuk melihat apakah data terdistribusi secara normal atau tidak. Dalam uji normalitas yang kita lihat untuk menentukan suatu variabel lulus uji normalitas atau tidak adalah dengan membandingkan hasil uji normalitas dalam tabel diatas diketahui nilai signifikansinya $0.200>$ 0.05 , maka dapat disimpulkan bahwa nilai residual berdistribusi normal. Dasar pengambilan keputusan adalah dengan grafik histogram dan P-Plot yaitu:

a. Data dikatakan berdistribusi normal, jika data dapat menyebar disekitar garis diagonal mengikuti arah garis diagonal atau grafik histogramnya.

b. Sebaliknya data dikatakan tidak berdistribusi normal, jika data menyebar jauh dari arah garis atau tidak mengikuti diagonal histogramnya.(Sugiyono 2006) Grafik 4.1

Histogram

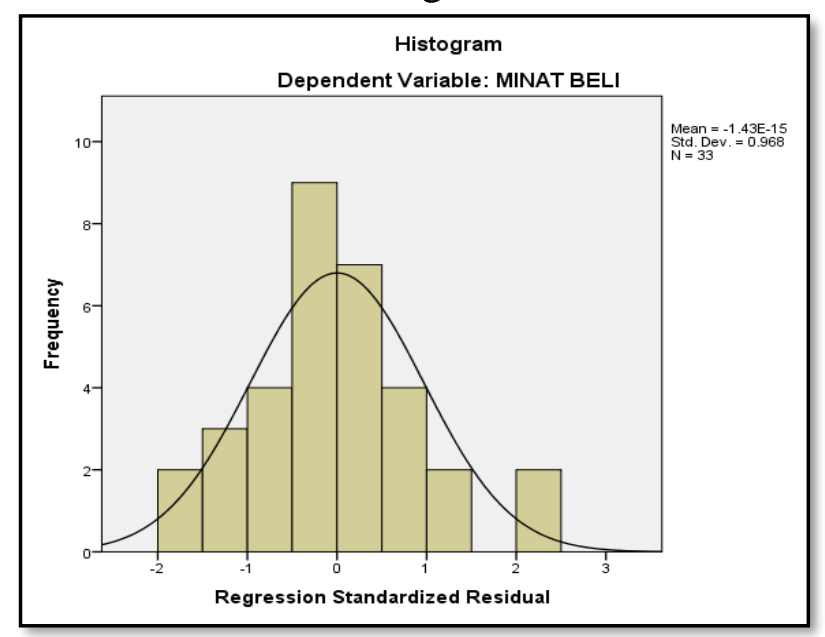

Sumber : Data Primer 2018 (Diolah)

Berdasarkan hasil uji terlihat bahwa Grafik Histogram memperlihatkan sebaran data menyebar ke seluruh daerah kurva normal, sehingga dapat dinyatakan bahwa data mempunyai distribusi normal.

Gambar 4.1

\section{Grafik Normal P-P}

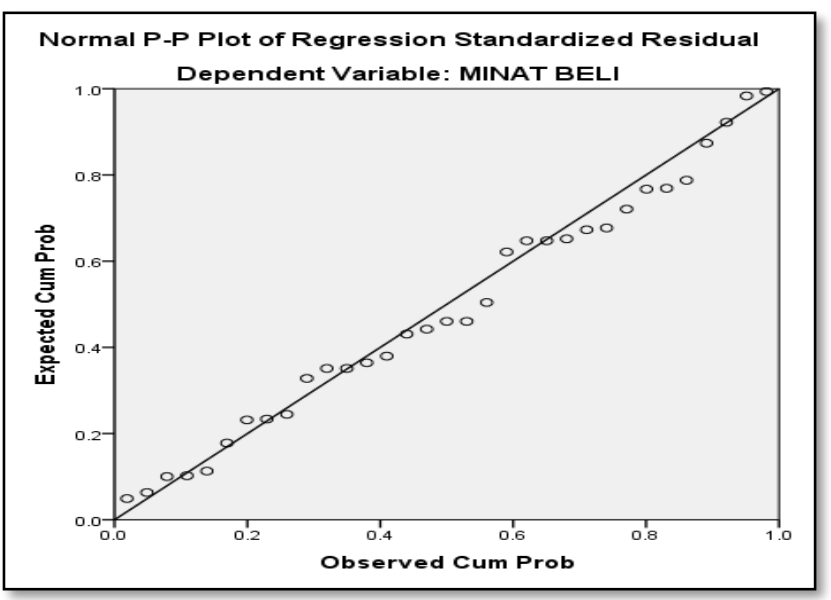

Sementara hasil uji menggunakan P-P Plot menunjukkan bahwa data mengikuti garis diagonal sehingga dinyatakan bahwa data berdistribusi normal.

\section{Uji Multikolinearitas}


Multikolinearitas adalah adanya hubungan linier antar variabel independen. Jadi uji multikolinearitas adalah untuk mengetahui ada tidaknya variabel independen yang memiliki kemiripan antar variabel independen dalam suatu model. Dalam uji multikolinearitas menggunakan metode Variance Inflation Faktor (VIF). Jika nilai $\mathrm{VIF}<10.00$ maka tidak terjadi multikolinearitas, namun jika nilai VIF > 10.00 maka terjadi multikolinearitas.

Tabel 4.6

Uji Multikolinearitas Coefficients $^{\mathrm{a}}$

\begin{tabular}{|l|l|c|r|}
\hline \multirow{2}{*}{\multicolumn{2}{|c|}{ Model }} & \multicolumn{2}{c|}{ Collinearity Statistics } \\
\cline { 2 - 4 } & Tolerance & VIF \\
\hline \multirow{2}{*}{1} & (Constant) & & \\
\cline { 2 - 4 } & & & 1.065 \\
\cline { 2 - 4 } & Faktor Sosial & .939 & 1.065 \\
\cline { 2 - 4 } & Faktor Pribadi & .939 & \\
\hline
\end{tabular}

Sumber : Data Primer 2018 (Diolah)

Dari tabel diatas dapat dilihat bahwa faktor sosial $\left(\mathrm{X}_{1}\right)$ dan faktor pribadi $\left(\mathrm{X}_{2}\right)$ nilai VIF $1.065<10.00$. Maka hal ini dapat disimpulkan bahwa tidak terjadi multikolinearitas antar variabel bebas dalam persamaan regresi. Dengan tidak terjadinya multikolinearitas maka persamaan ini layak digunakan.

\section{Uji Heteroskedastisitas}

Tujuan melakukan uji heteroskedastisitas adalah untuk menguji apakah dalam model regresi terjadi ketidaksamaan variance dari residual satu pengamatan ke pengamatan yang lain. Ada beberapa metode untuk melakukan uji heteroskedastisitas, kali ini peneliti menggunakan metode Glejser. Jika nilai signifikansi $>0.05$ artinya tidak terjadi heteroskedastisitas namun jika nilai signifikansi $<0.05$ artinya terjadi heteroskedastisitas. Hasil uji heteroskedastisitas bisa dilihat dalam tabel dibawah ini.

Tabel 4.7
Uji Heteroskedastisitas Glejser

\begin{tabular}{|c|c|c|c|c|c|c|}
\hline \multicolumn{7}{|c|}{ Coefficients $^{\mathbf{a}}$} \\
\hline & \multirow[t]{2}{*}{ Model } & \multicolumn{2}{|c|}{$\begin{array}{l}\text { Unstandardized } \\
\text { Coefficients }\end{array}$} & \multirow{2}{*}{$\begin{array}{c}\text { Stand- } \\
\text { ardized } \\
\text { Coeffi- } \\
\text { cients } \\
\text { Beta } \\
\end{array}$} & \multirow[t]{2}{*}{$\mathrm{T}$} & \multirow[t]{2}{*}{ Sig. } \\
\hline & & $\mathrm{B}$ & Std. Error & & & \\
\hline \multirow[t]{3}{*}{1} & (Constant) & .866 & 1.363 & & .636 & .530 \\
\hline & $\begin{array}{l}\text { Faktor So- } \\
\text { sial }\end{array}$ & -.139 & .068 & -.355 & 2.044 & .060 \\
\hline & \begin{tabular}{|l|} 
Faktor \\
Pribadi
\end{tabular} & .105 & .0 .68 & .269 & 1.552 & .131 \\
\hline
\end{tabular}

Dapat dilihat dari tabel diatas bahwa nilai signifikansi X1 $0.060>0.05$ artinya tidak terjadi heteroskedastisitas dan nilai signifikansi $\mathrm{X} 20.131>0.05$ artinya tidak terjadi heteroskedastisitas.

\section{Uji Parsial (Uji T)}

Uji t bertujuan untuk mengetahui ada atau tidaknya pengaruh parsial (sendiri) yang diberikan variabel bebas $(\mathrm{X})$ terhadap variabel terikat (Y).

\section{Tabel 4.8}

\begin{tabular}{|c|c|c|c|c|c|}
\hline \multicolumn{6}{|c|}{ Hasil Uji T } \\
\hline \multicolumn{6}{|c|}{ Coefficients $^{\mathbf{a}}$} \\
\hline \multirow{2}{*}{ Model } & \multicolumn{2}{|c|}{$\begin{array}{c}\text { Unstandardized } \\
\text { Coefficients }\end{array}$} & \multirow{2}{*}{\begin{tabular}{|c}
$\begin{array}{c}\text { Standard- } \\
\text { ized Co- } \\
\text { efficients }\end{array}$ \\
Beta \\
\end{tabular}} & \multirow[t]{2}{*}{$\mathrm{t}$} & \multirow{2}{*}{ Sig. } \\
\hline & B & $\begin{array}{l}\text { Std. } \\
\text { Error }\end{array}$ & & & \\
\hline \begin{tabular}{l|l}
1 & (Constant)
\end{tabular} & $\begin{array}{r}11.58 \\
9\end{array}$ & 2.405 & & 4.820 & .000 \\
\hline $\begin{array}{l}\text { Faktor Sosial } \\
\text { (X1) }\end{array}$ & .232 & .120 & .254 & 1.933 & .063 \\
\hline $\begin{array}{l}\text { Faktor Pribadi } \\
\text { (X2) }\end{array}$ & .556 & .119 & .611 & 4.660 & .000 \\
\hline
\end{tabular}

Dari hasil output pengujian data uji $t$ menggunakan aplikasi SPSS 22 tersebut dapat dilihat nilai signifikansi masing-masing variabel Sosial $\left(\mathrm{X}_{1}\right)$, Pribadi $\left(\mathrm{X}_{2}\right)$. Suatu variabel $\mathrm{X}$ berpengaruh terhadap variabel Y jika nilai signifikansinya $<0.05$. Maka dapat disimpulkan bahwa variabel sosial $\left(\mathrm{X}_{1}\right)$ tidak berpengaruh terhadap minat beli konsumen karena mempunyai nilai signifikansi sebesar $0.063>0.05$. Namun nilai signifikansi variabel pribadi (X2) sebesar $0.000<0.05$ sehingga dapat dikatakan 
bahwa variabel pribadi berpengaruh signifikan terhadap minat beli konsumen makanan tanpa tanggal kedaluwarsa.

\section{Uji Simultan (Uji F)}

Uji $f$ bertujuan untuk mengetahui ada atau tidaknya pengaruh simultan (bersama-sama) yang diberikan variabel bebas (X) terhadap variabel terikat $(\mathrm{Y})$. berikut ini merupakan tabel hasil uji f. Berikut ini merupakan hasil dari uji simultan (Uji F) hasil dari pengujiannya ditampilkan pada tabel berikut:

Table 4.9

Hasil Uji F

\begin{tabular}{|l|l|r|r|r|r|r|}
\hline \multicolumn{7}{|c|}{ ANOVA $^{\mathrm{a}}$} \\
\hline \multicolumn{2}{|c|}{ Model } & $\begin{array}{l}\text { Sum of } \\
\text { Squares }\end{array}$ & \multicolumn{1}{c|}{ Df } & $\begin{array}{c}\text { Mean } \\
\text { Square }\end{array}$ & \multicolumn{1}{c|}{ F } & Sig. \\
\hline \multirow{2}{*}{1} & $\begin{array}{l}\text { Regres- } \\
\text { sion }\end{array}$ & 82.320 & 2 & 41.160 & $\begin{array}{r}15.92 \\
1\end{array}$ & $.000^{\mathrm{b}}$ \\
\cline { 2 - 8 } & Residual & 77.559 & 30 & 2.585 & & \\
\cline { 2 - 8 } & Total & 159.879 & 32 & & & \\
\hline
\end{tabular}

Dari tabel diatas menunjukkan hasil uji $\mathrm{f}$ sehingga dapat disimpulkan apakah variabelvariabel yang dimasukan dalam penelitian memilki pengaruh terhadap minat beli konsumen makanan tanpa tanggal kedaluwarsa yaitu dengan melihat nilai signifikansinya. Nilai signifikansinya memiliki nilai sebesar $0.000<0.05$ sehingga dapat disimpulkan bahwa variabel sosial $\left(\mathrm{X}_{1}\right)$ dan pribadi $\left(\mathrm{X}_{2}\right)$ secara bersama-sama dapat mempengaruhi minat beli konsumen makanan tanpa tanggal kedaluwarsa.

\section{Uji R-squared (Uji R2)}

Fungsi dari uji koefisien adalah mengetahui berapa persen pengaruh yang diberikan variabel $X$ secara simultan terhadap variabel Y. hasil pengujiannya adalah sebagai berikut:

Tabel 4.10

Hasil Uji R Square

\begin{tabular}{|c|c|c|c|c|}
\hline \multicolumn{5}{|c|}{ Model Summary } \\
\hline Model & R & R Square & $\begin{array}{c}\text { Adjusted } \\
\text { R Square }\end{array}$ & $\begin{array}{c}\text { Std. Error } \\
\text { of the Es- } \\
\text { timate }\end{array}$ \\
\hline
\end{tabular}

\begin{tabular}{|l|r|r|r|r|}
\hline 1 & $.718^{\mathrm{a}}$ & .515 & .483 & 1.60788 \\
\hline
\end{tabular}

Berdasarkan output diatas diketahui nilai $\mathrm{R}$ Square sebesar 0.515 hal ini mengandung arti bahwa pengaruh variabel $\mathrm{X} 1$ dan $\mathrm{X} 2$ secara simultan terhadap Y sebesar 51,1\%.

\section{C.Pengaruh Faktor Sosial Terhadap Minat Beli Produk Peyek Aziz Tanpa Tanggal Kedaluwarsa Dalam Perspektif Ekonomi Syariah}

Suatu variabel $\mathrm{X}$ berpengaruh terhadap variabel $\mathrm{Y}$ jika nilai signifikansinya $<0.05$. Berdasarkan hasil uji t menggunakan aplikasi SPSS 22 dihasilkan nilai signifikansi variabel Sosial $\left(X_{1}\right)$ sebesar $0.063>0.05$, artinya lebih besar dari 0,05 , sehingga dapat disimpulkan bahwa variable factor social tidak berpengaruh signifikan terhadap minat beli produk Peyek Aziz tanpa tanggal kedaluwarsa dalam perspektif ekonomi syariah

\section{D.Pengaruh Faktor Pribadi Terhadap Minat Beli Produk Peyek Aziz Tanpa Tanggal Kedaluwarsa Dalam Perspektif Ekonomi Syariah}

Suatu variabel $X$ berpengaruh terhadap variabel Y jika nilai signifikansinya $<0.05$. Berdasarkan hasil uji t menggunakan software SPSS 22 dihasilkan nilai signifikansi variabel pribadi $\left(\mathrm{X}_{2}\right)$ sebesar $0.000<0.05$, artinya lebih kecil dari 0,05, sehingga dapat disimpulkan bahwa variabel pribadi berpengaruh signifikan terhadap minat beli produk Peyek Aziz tanpa tanggal kedaluwarsa dalam perspektif ekonomi Syariah.

\section{E. Pengaruh Faktor Sosial Dan Pribadi Terhadap Minat Beli Produk Peyek Aziz Tanpa Tanggal Kedaluwarsa Dalam Perspektif Ekonomi Syariah \\ Berdasarkan hasil uji simultan (F) variable $\mathrm{X}_{1}$ (Faktor Sosial) dan $\mathrm{X}_{2}$ (Pribadi) dihasilkan nilai signifikansi sebesar $0.000<0.05$, artinya}


lebih kecil dari 0,05, sehingga dapat disimpulkan bahwa variabel factor sosial $\left(\mathrm{X}_{1}\right)$ dan factor pribadi $\left(\mathrm{X}_{2}\right)$ secara bersama-sama berpengaruh terhadap minat beli produk Peyek Aziz tanpa tanggal kedaluwarsa dalam perspektif ekonomi Syariah. Berdasarkan hasil uji R-Square faktor sosial dan faktor pribadi memiliki pengaruh sebe-sar 0.515 atau sebesar $51,5 \%$ terhadap minat beli konsumen. Sedangkan sisanya sebesar $48.5 \%$ dipengaruhi oleh faktor lain yang tid-ak diteliti pada penelitian saat ini.

\section{F. Pandangan Ekonomi Syariah Terhadap Produk Makanan Tanpa Tanggal Ked- aluwarsa}

Pandangan Ekonomi Syariah terhadap makan tanpa label kedaluwarsa secara umum tidak ditemui dasar hukumnya pada al-Quran dan Hadits. Dalam ajaran fiqh, Islam mengajarkan umatnya untuk mengkonsumsi sesuatu yang halal dan baik. Baik itu dari segi manfaat makanannya maupun dari cara memperolehnya. Pembahasan secara dasar hukum yang tertulis dalam al-Quran dan Hadits terkait makanan yang dibolehkan dan di haramkan untuk dikonsumsi berkaitan dengan makanan tanpa kedaluwarsa yang belum ditemukan pembahasannya, hal ini dimungkinkan pembahasan label kedaluwarsa masuk menjadi pembahasan pemikiran dalam kaidah fiqh di masa-masa modern seperti sekarang ini sehingga telaah fiqh dimasa lalu belum ditemui pembahasannya (Nukeriana 2018). Dengan demikian pandangan ulama saat ini dengan merujuk pada contoh kasus yang mirip/serupa dapat menyandarkan hukum pendapatnya. Dengan demikian pemikiran seperti ini menjadi ijtihad ulama dalam menghasilkan kaidah fiqh keontemporer (Fakhrina and others 2017).

Menurut Ust Dadan Abdul Rohman Ukuran Kebolehan Mengkonsumsi Makanan Yang Telah Jelas Halal Berdasarkan Label
Kedaluwarsa yang tidak dicantumkan adalah dengan mempertimbangkan kemaslahatan yang diperoleh dan kemadharatan yang ditimbulkan setelahnya (Kertamukti 2019).

Kemaslahatan dan kemadharatan yang di timbulkan menurut Abdul Wahhab Khallaf dalam penjelasannya menjelaskan bahwa hal ini merupakan mashlahah mursalah berarti sesuatu yang dianggap maslahat namun tidak ada ketegasan hukum untuk merealisasikannya dan tidak pula ada dalil tertentu baik yang mendukung maupun yang menolaknya (Mahfudin and Fatikha 2020).

Menurut Imam Ghazali menjelaskan secara terminologi bahwa kemaslahatan atau mashlahah adalah mengambil manfaat dan menolak kemudharatan dalam rangka memelihara tujuan syara'. disamping itu dalam ushul fiqh upaya mewujudkan kemaslahatan dari permasalahan-permasalahan yang ditemui dan tidak ada dasar hukum yang tertulis secara jelas maka berlaku kaidah "Adh-Dhararu $Y u$ zaalu" atau menghindari kemudharatan sebisa mungkin.

Kaidah Adh-Dhararu Yuzaalu" atau menghindari kemudharatan sebisa mungkin memiliki sudut pandang yang berkaitan dengan kemudharatan yang terjadi di antara para hamba, dimana kemudharatan, kesulitan, dan sejenisnya sebisa mungkin dihilangkan di antara para hamba (Sanusi 2020). Dengan demikian menurut kaidah fiqh.

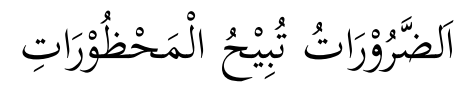

"Keadaan darurat membolehkan sesuatu yang sebelumnya haram"

Berdasarkan kaidah diatas dapat dikaitkan dengan contoh yang telah dipaparkan oleh jumhur ulama yakni "apabila seseorang diserang oleh orang jahat, maka tidak mengapa baginya untuk membela dirinya lantas membunuh orang jahat tersebut demi menghindarkan kemudharatan (kematian) itu terjadinya pada dirinya walaupun harus membunuhnya". 
Berdasarkan pada pemaparan diatas dapat di tarik pemahaman bahwa jumhur ulama bersepakat bahwa segala kemudharatan apapun bentuknya adalah hal yang terlarang yang harus dihilangkan. Hal ini merupakan penerapan atas kaidah ألََّرَرُ يُزَ الْ Adh-Dhararu Yuzaalu”, atau menghindari kemudharatan sebisa mungkin dengan berbagai contoh langsung yang berikan Allah SWT dalam firman-Nya yang diartikan bahwa segala hal yang dapat menimbulkan kemudharatan harus dihilangkan. Berikut beberapa contoh yang diuraikan yang berkaitan dengan kehidupan sehari-hari:

1.Dua orang yang telah selesai melakukan transaksi jual beli. Misal, seorang pembeli membeli sebuah mobil kepada seorang penjual dengan harga yang jauh melebihi harga pasaran. Setelah si pembeli mengetahui bahwa dia dibohongi dan merasa dirugikan dengan harga jual yang terlalu mahal (ghabn) tersebut, maka dia berhak mengajukan khiyar ghabn ke pengadilan. Bentuknya dengan diberikan kesempatan kepadanya untuk memilih apakah dia tetap lanjutkan pembelian, atau dia batalkan, atau dia memilih tetap membeli tetapi mengambil ganti rugi. Atau dalam kasus yang lain dia ditipu, maka dia berhak mengajukan khiyar tadlis. Atau dia membeli barang tetapi barang tersebut cacat, maka dia berhak mengajukan khiyar 'aib, dengan bentuk penawaran yang sama dengan khiyar ghabn. Semua bentuk khiyar ini disyariatkan salah satunya dalam rangka untuk menolak kemudharatan.

2.Seseorang yang memonopoli suatu jenis barang atau makanan lalu dia menyimpannya. Ketika harga pasar barang tersebut naik, dia menjualnya dengan harga yang tidak wajar. Maka pemerintah berhak untuk memaksanya agar menjualnya kembali dengan harga yang wajar.
3. Seseorang yang punya talang air di depan rumahnya sehingga air dari rumahnya tersebut mengarah ke jalan umum. Maka pemerintah berhak untuk menyuruhnya agar memasukkan talang tersebut ke bagian rumahnya.

Berikut ini pendapat lain dari ulama lainnya berkaitan dengan mashlahah mursalah, menurut Abdul Karim Zaidan macammacam mashlahah mursalah dapat di uraikan penjelasan sebagai berikut (Syarifuddin 2018):

1.Al-Mashlahah al-Mu'tabarah, yaitu mashlahah yang secara tegas diakui syariat dan telah ditetapkan ketentuan-ketentuan hukum untuk merealisasikannya. Misalnya, diperintahkan berjihad untuk memelihara agama dari rong-rongan musuhnya

2.Al-maslahah al-mulgah, yaitu sesuatu yang dianggap mashlahah oleh akal pikiran, tetapi dianggap palsu karena kenyataannya bertentangan dengan ketentuan syariat. Misalnya, ada anggapan bahwa menyamakan pembagian warisan antara anak laki-laki dan anak wanita adalah mashlahah. Akan tetapi, kesimpulan seperti ini bertentangan dengan ketentuan syarait, yaitu ayat Surat an-Nisa' yang menegaskan bahwa pembagian anak lakilaki dua kali pembagian anak perempuan. Adanya pertentangan ini menunjukkan bahwa apa yang dianggap maslahat itu bukan maslahat disisi Allah.

3.Al-Mashlahah al-Mursalah, dan maslahat semacam inilah yang dimaksud dalam pembahasan ini, yang pengertiannya adalah seperti definisi yang disebutkan di awal. Maslahat macam ini terdapat dalam masalah-masalah muamalah yang tidak ada ketegasan hukumnya dan tidak ada pula perbandingannya di dalam al-Qur'an dan Sunnah untuk dapat dilakukan 
analogi. Contohnya, peraturan pencantuman batas layak konsumsi pada produk makanan. Peraturan seperti ini tidak ada dalil khusus yang mengaturnya, baik dalam Alquran maupun dalam Sunnah Rasulullah. Namun, peraturan seperti itu sejalan dengan tujuan syariat, yaitu dalam hal ini adalah untuk memelihara jiwa dan harta.

Menurut Abdul Wahhab Khallaf menjelaskan beberapa persyaratan dalam memfungsikan mashlahah mursalah, yaitu:

1. Sesuatu yang dianggap maslahat itu haruslah berupa maslahat hakiki yaitu yang benar-benar akan mendatangkan kemanfaatan atau menolak kemudaratan, bukan berupa dugaan belaka dengan hanya mempertimbangkan adanya kemanfaatan tanpa melihat kepada akibat negatif yang ditimbulkannya.

2. Sesuatu yang dianggap maslahat itu hendaklah berupa kepentingan umum, bukan kepentingan pribadi. Sesuatu yang dianggap maslahat itu tidak bertentangan dengan ketentuan yang ada ketegasan dalam Alquran atau Sunnah Rasulullah SAW, atau bertentangan dengan ijma'.

Berdasarkan penjelasan diatas, keterkaitan dengan penelitian yang dilakukan maka dapat ditarik pemahaman bahwa:

1.Pencantuman batas layak konsumsi pada setiap produk makanan kemasan telah sesuai dengan syarat di atas. Penjelasannya adalah sebagai berikut:

2.Penetapan batas kadaluwarsa menghasilkan kemanfaatan yang lebih besar, hal ini sebagai informasi yang mempermudah konsumen dalam memilih produk.

3. Sesuatu yang dianggap maslahat hendaklah berupa kepentingan umum bukan kepentingan pribadi. Pencantuman kadaluwarsa pada produk makanan yang diedarkan dikalangan masyarakat luas dilakukan untuk kepentingan masyarakat umum., hal Ini merupakan bentuk perlindungan terhadap konsumen agar terhindar dari hal-hal yang dapat merugikan konsumen.

4.Sesuatu yang dianggap maslahat tidak bertentangan dengan alquran, sunnah dan ijma'. Walaupun tidak ada dalil khusus yang mengatur tentang peraturan pencantuman batas layak konsumsi, namun hal ini tidaklah bertentangan dengan al-Qur'an, sunnah dan ijma', tapi mendatangkan manfaat yang nyata dan jelas. Dengan demikian pencantuman batas layak konsumsi tersebut merupakan upaya menjalankan syariat dengan tidak bertentangan dengan syara' dan menjadi tujuan dari syariat, yaitu untuk memelihara jiwa dan harta. Berdasarkan pembahasana dan contoh kasus diatas, maka dapat ditarik pemahaman yakni kaitannya dengan tinjauan ekonomi syariah terhadap makanan tanpa label kedaluwarsa adalah bahwa penerapan label kedaluwarsa pada makanan merupakan upaya dalam memberi kejelasan batas waktu baik untuk mengkonsumsi produk makanan tersebut. Dengan demikian peyek Aziz yang belum mencantumkan label kedaluwarsa secara syariat Islam tidak bertentangan dengan hukum syara'. hal ini didasarkan kepada kemaslahatan yang di timbulkan dari produk peyek yang memberikan kebutuhan terhadap konsumen dinilai lebih besar. Disamping itu konsumen masih secara dengan mudah melakukan pengecekan visual terhadap peyek Aziz yakni dengan melihat secara langsung produk dan menguji kerenyahan mematahkan sedikit bagian dari meproduk tersebut. Proses metahkan sedikit dari bagian dimaksudkan untuk menguji kerenyahan dengan dasar bahwa jika bagus produk tersebut di beli dan jika tidak makan di kembalikan kepada pembuat peyek.

Dengan demikian makanan tanpa label kedaluwarsa di ditinjau dari ekonomi syariah 
dapat tarik kesimpulan bahwa tidak mencantumkan label kedaluwarsa tidak dinilai menjadi hal yang diharamkan, sebaliknya mencantumkannya menjadi sebuah upaya dalam memelihara jiwa dan harta. Hal ini juga diperkuat dengan firman Allah SWT.

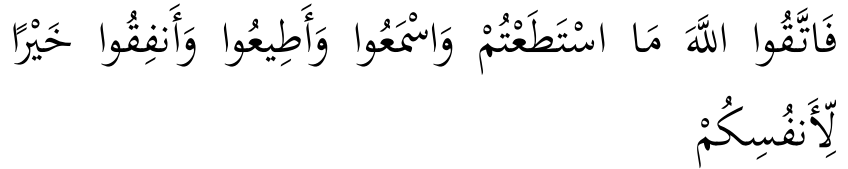

"Maka bertakwalah kamu kepada Allah menurut kesanggupanmu dan dengarlah serta taatlah dan nafkahkanlah nafkah yang baik untuk dirimu"

\section{KESIMPULAN}

Berdasarakan hasil pembahasan diatas maka dapat disimpulkan bahwa variable faktor social tidak berpengaruh signifikan terhadap minat beli produk Peyek Aziz tanpa tanggal ked-aluwarsa dalam perspektif ekonomi syariah, karena Suatu variabel X berpengaruh terhadap variabel Y jika nilai signifikansinya $<0.05$. Berdasarkan hasil uji $t$ menggunakan aplikasi SPSS 22 dihasilkan nilai signifikansi variabel Sosial $\left(\mathrm{X}_{1}\right)$ sebesar $0.063>0.05$, artinya lebih besar dari 0,05.

Selanjutnya variabel factor pribadi berpengaruh signifikan terhadap minat beli produk Peyek Aziz tanpa tanggal kedaluwarsa dalam perspektif ekonomi Syariah, karena mempunyai nilai segnifikansi sebesar $0.000<$ 0.05 , artinya lebih kecil dari 0,05.

Berikutnya variabel faktor sosial $\left(\mathrm{X}_{1}\right)$ dan faktor pribadi $\left(\mathrm{X}_{2}\right)$ secara bersama-sama berpengaruh terhadap minat beli produk Peyek Aziz tanpa tanggal ked-aluwarsa dalam perspektif ekonomi Syariah, karena dihasilkan nilai signifikansi sebesar $0.000<0.05$, artinya lebih kecil dari 0,05. Berdasarkan hasil uji RSquare faktor sosial dan faktor pribadi memiliki pengaruh sebesar 0.515 atau sebesar $51,5 \%$ terhadap minat beli konsumen. Sedangkan sisanya sebesar $48.5 \%$ dipengaruhi oleh faktor lain yang tidak diteliti pada penelitian saat ini.
Pandangan ekonomi syariah terhadap produk makanan tanpa tanggal kedaluwarsa pada makanan tidak ditemukan aturan yang khusus mengatur secara tertulis. Pencantuman label kedaluwarsa merupakan ijtihad dalam memberi informasi batas waktu layak konsumsi pada produk makanan dengan tujuan kemaslahatan dalam memelihara harta dan jiwa.

\section{DAFTAR PUSTAKA}

Arikunto, Suharsimi. 2016. Manajemen Penelitian. Jakarta: Rineka Cipta.

Bourdieu Piere. 2015. Aneka Produksi Kultural. Yogyakarta: Kreasi Wacana.

Enang, Sudrajat. 2010. Al-Qur'an Dan Terjemah. Bandung: PT Madina Raihan Makmur.

Fahmi, Irham. 2016. Perilaku Konsumen Teori Dan Aplikasi. Bandung: Alfabeta.

Fakhrina, Nur Aina, and others. 2017. "Jual Beli Produk Makanan Tanpa Pencantuman Batas Layak Konsumsi Menurut Hukum Islam (Studi Kasus Pada Sentra Penjualan Kue Tradisional Di Desa Lampisang)." UIN Ar-Raniry Banda Aceh.

Haris Hamid. 2017. Hukum Perlindungan Konsumen Indonesia. Makasar: Cv Sah Media.

Idri. 2017. Hadis Ekonomi Dalam Perspektif Hadis Nabi, Cetakan 3. Jakarta: Kencana Prenada Media Group.

Isnaini Harahap Dkk. 2015. Hadits-Hadits Ekonomi. Jakarta: Kencana Prenadamedia Group.

Juliansyah Noor. 2011. Metodologi Penelitian Skripsi, Tesis, Disertasi Dan Karya Ilmiah. Jakarta: Kencana Prenada Media Group.

Kertamukti, Ust Dadan Abdul Rohman 
Selaku Tokoh Agama Desa. 2019. "Wawancara Tentang Ukuran Kebolehan Mengkonsumsi Makanan Yang Telah Jelas Halal Berdasarkan Label Kedaluwarsa."

Lidyawatie. 2008. Manajemen Pemasaran Dan Pemasaranm Jasa. Bandung: Alfabeta.

Mahfudin, Agus, and Ilmiati Fatikha. 2020.

"Tinjauan Mashlahah Mursalah Tentang Donor Air Susu Ibu Di Lactashare Malang." Jurnal Hukum Keluarga Islam 5, no. 2: 180-98.

Moh. Nazir. 2014. Metode Penelitian. Bogor: Ghalia Indonesia.

Mudrajad Kuncoro. 2014. Metode Riset Untuk Bisnis Dan Ekonomi. Jakarta: Erlangga.

Muslim, Al-Imam Abi al-Husaini. 1998. Shahih Muslim. 2nd ed. Bairut: Dâr alKutub al-'Ilmiyyah.

Nukeriana, Debbi. 2018. "Implementasi Sertifikasi Halal Pada Produk Pangan Di Kota Bengkulu." Qiyas: Jurnal Hukum Islam Dan Peradilan 3, no. 2: 154-65.

Payne Andrian. 2009. Services Marketing Pemasaran Jasa. Yogyakarta: Andi.

Peter, J Paul dan Olson, Jerry C. 2010. Consumer Behavior: Perilaku Konsumen Dan Strategi Pemasaran, Edisi Keempat. Jakarta: Erlangga.

Sanusi, Ahmad. 2020. "Teori Maqoshid Syariah Dan Penerapannya Pada Fatwa Korona (Studi Analisis Kritis)." Syakhsia: Jurnal Hukum Perdata Islam 21, no. 1: 1-38.

Sarastri Mumpuni dan Idea Prajna Paramitha. 2013. "Pelatihan Penyempurnaan Produk Peyek Rebon." Inovasi Dan Kewirausahaan 2, no. 3: 154-57.

Shihab, M. Quraish. 2002. Tafsir Al-Misbah.
Jakarta: Lentera Hati.

Shinta Agustina. 2011. Manajemen Pemasaran. Malang: UB Press.

Simamora Bilson. 2003. Memenangkan Pasar Dengan Pemasaran Efektif Dan Profitabel. Jakarta: PT Gramedia Pustaka Utama.

Sugiyono. 2006. Statistika Untuk Penelitian. Bandung: cv Alfabeta.

Syamsuddin, and Vismaia Damaianti. 2011. Metode Penelitian Pendidikan Bahasa. Bandung: PT. Remaja Rosdakarya.

Syarifuddin, Moh. 2018. "Maslahah Sebagai Alternatif Istinbath Hukum Dalam Ekonomi Syari'ah." Jurnal Lentera: Kajian Keagamaan, Keilmuan Dan Teknologi 17, no. 1: 46-61.

EKSISBANK (Ekonomi Syariah dan Bisnis Perbankan), Volume 5, Nomor 2, Desember 2021 